accuracy and reproducibility (mean error $-10 \%$, standard deviation $\pm 36 \%$ ). Blood loss of the order of 400 to $500 \mathrm{ml}$. can be measured with greater reproducibility $(-12 \%, \pm 26 \%)$. However, blood loss of the order of 700 to $3,000 \mathrm{ml}$. computed from consecutive whole-body counts over periods of time ranging from 1 to 97 days can be measured with sufficient accuracy and reproducibility $(-0.2 \%, \pm 14 \%)$ to be of use in the quantitative assessment of blood loss in patients with hypochromic anaemia, over periods of up to three months.

Although a whole-body counter has previously been applied to clinical problems of blood loss (Price et al., 1964), the technique has never been evaluated critically. Price et al. calculated menstrual blood loss against a direct measurement of the ${ }^{59} \mathrm{~F}=$ - ontent of tampons in one case, and thought an error of $26-40 \mathrm{ml}$. in losses amounting to $33-59 \mathrm{ml}$. was likely. Nevertheless it is probably wrong to assume that blood loss occurring clinically can be measured with the same precision as was attained with venesection of patients with polycythaemia. Gastrointestinal or menstrual bleeding may occur erratically and lead to fluctuations in the red cell content of ${ }^{59} \mathrm{Fe}$ and blood volume, both of which cannot be corrected for.

By the above method we are unable to measure reliably blood loss of the order of $100 \mathrm{ml}$., and an accurate assessment of a single moderately heavy menstrual period is not possible. However, a more accurate measurement is possible if the patient is followed over three or four menstrual cycles.

The ease and simplicity of the technique described here is such that all the studies were carried out on subjects visiting the department as outpatients. The technique is now available in this hospital as a diagnostic service and is being used to study the mechanism of naemia in patients with hiatus hernia, ulcerative colitis, and Crohn's disease.

\section{Summary}

A method is described for the measurement of blood loss over periods of up to three months by means of ${ }^{59} \mathrm{Fe}$ and a whole-body counter. Patients with polycythaemia from whom known quantities of blood were removed by venesection were studied to evaluate this technique. The method is sensitive and accurate enough for clinical purposes, and blood loss of more than $700 \mathrm{ml}$. can be measured with reproducibility of $\pm 14 \%$. To illustrate its application to clinical problems, studies of five cases of hypochromic anaemia are described.

We wish to thank Miss Marjorie Alcock for technical assistance. The work was in part supported by a grant from the Medical Research Council.

REPERENCES

Callender, S. T., Witts, L. J., Warner, G. T., and Oliver, R. (1966). Brit. F. Haemat., 12, 276.

Price, D. C., Forsyth, E. M., Cohn, S. H., and Cronkite, E. P. (1964). Canad. med. Ass. 7., 90, 51.

Warner, G. T., and Oliver, R. (1966). Phys. in Med. Biol., 11, 83.

Wasserman, L., R., Tse-fei, Y., and Rashkoff, I. A. (1951). 7. Lab. clin. Med., 37, 342 .

\title{
Effect of Transfusion Materials on Rouleaux Formation and Sedimentation Rate of Erythrocytes
}

\author{
A. J. SALSBURY,* M.D.
}

Brit. med. F., 1967, 4, 88-90

The range and variety of plasma expanders and plasma substitutes are constantly increasing, particularly in the case of dextran solutions (Mollison, 1967 ; Brit. med. f., 1967). A relatively new dextran is dextran 110, which has a high molecular weight though lower than that of the longer-established dextran 150. Ricketts (1966) has investigated the properties of a modified dextran similar to dextran 110 . He found that the effect of this dextran on the red-cell sedimentation rate was substantially less than that of dextran 150 and that red-cell aggregation in the rabbit was minimal. Rouleaux formation was found to interfere with cross-matching in only two out of nine patients who received modified dextran.

In view of these results, it was decided to undertake a series of investigations in vitro to determine the effect of dextran 110, dextran 150, Macrodex, a commercial plasma protein solution, and plasma itself upon red-cell rouleaux formation, blood typing, and cross-matching.

\section{Methods and Results}

In the experiments the following standard transfusion materials were compared: (1) reconstituted dried human plasma ; (2) a commercial $4.3 \%$ plasma protein solution (Serological Products Ltd.) ; (3) $6 \% \mathrm{w} / \mathrm{v}$ Macrodex in normal saline (Pharmacia (Great Britain) Ltd.) ; (4) $6 \% \mathrm{w} / \mathrm{v}$ dextran

\footnotetext{
- Department of Haematology, St. Bartholomew's Hospital, London E.C.1.
}

110 in normal saline (Fisons Pharmaceuticals Ltd.) ; (5) 6\% $\mathrm{w} / \mathrm{v}$ dextran 150 in normal saline (Fisons Pharmaceuticals Ltd.). As a control, tests were also set up with normal saline in place of one of the above substances. All samples of blood were taken from healthy human volunteers into Sequestrene (sodium edetate). The Westergren sedimentation rate of each sample was $2 \mathrm{~mm}$. in the first hour. Three main sets of experiments were then performed.

Effect of Varying Concentrations of Transfusion Materials on the E.S.R.-The transfusion materials listed above were mixed with blood in dilutions of 1 in 10, 1 in 20, and 1 in 40 (Table I). Five different samples of blood were tested (Tests A-E). Citrate was added to each mixture and the samples were set up in Westergren tubes at room temperature, results being read at the end of one hour. The substitution of plasma or plasma protein solution for saline had no effect on the sedimentation rate (Table $I$ ). The substitution of dextran 150 markedly raised the E.S.R. The effect of dextran 110 was less pronounced, but still considerable, while that of Macrodex was moderate. The greater the concentration of Macrodex, dextran 110, or dextran 150, the greater their effect on the E.S.R. This increased effect, however, was much less pronounced with Macrodex than with dextran 110 or dextran 150 .

Effect of Transfusion Materials and Anaemia on the E.S.R. - The concentration of transfusion material added to blood was kept constant at 1 in 10 . Three different samples of blood were used (Tests I-III). The samples were adjusted by centrifugation and reconstitution of cells and plasma to give haemo- 
globin levels ranging between 30 and $110 \%$, before any transfusion material was added. Westergren sedimentation rates were investigated as in the first set of experiments. The results (Table II) essentially resembled those of the first set of experiments. The sedimentation rate was unaffected by plasma or plasma-protein solution and only moderately affected by Macrodex, even in the specimens with the lowest haemoglobin concentrations. Nevertheless, dextran 110 and dextran 150 produced a striking increase in the E.S.R., which became more pronounced as the haemoglobin concentration in the blood specimen fell.

Effect of Transfusion Materials upon Cross-matching.Mock saline cross-matching tests were set up in this experiment. Five samples of normal blood were made up as $5 \%$ red-cell suspensions in normal saline. Single drops of each suspension were placed in precipitin tubes. To each was added one drop of serum from the corresponding subject, containing a 1 in 10 dilution of the appropriate transfusion material. The tubes were incubated at $37^{\circ} \mathrm{C}$. for two hours. At the end of this time any red-cell aggregation visible to the naked eye was noted and the results were read microscopically. No macroscopic red-cell aggregation or microscopical rouleaux formation was observed in the tubes containing saline, plasma, or plasmaprotein solution. With Macrodex a fine granularity was visible

TABLE I.-Effect on Erythrocyte Sedimentation Rate of Varying
Concentrations of Transfusion Materials

\begin{tabular}{|c|c|c|c|c|c|c|c|c|c|}
\hline & & & \multirow{2}{*}{$\underset{(\mathrm{ml} .)}{\text { Citrate }}$} & \multirow{2}{*}{$\begin{array}{c}\text { Blood } \\
\text { (ml.) }\end{array}$} & \multicolumn{5}{|c|}{ E.S.R. (mm. in 1st hour) (Westergren) } \\
\hline & & & & & Test A & Test B & Test C & Test D & Test $\mathrm{E}$ \\
\hline Saline & $\left\{\begin{array}{l}0.05 \mathrm{n} \\
0.1 \\
0.2\end{array}\right.$ & $\begin{array}{c}\mathrm{ml} \text {. } \\
\text { ") }\end{array}$ & 0.5 & $\begin{array}{l}1.95 \\
1.90 \\
1.80\end{array}$ & $\begin{array}{l}1 \\
1 \\
1\end{array}$ & $\begin{array}{l}2 \\
1 \\
2\end{array}$ & $\begin{array}{l}2 \\
2 \\
3\end{array}$ & $\begin{array}{l}4 \\
3 \\
4\end{array}$ & $\begin{array}{l}2 \\
2 \\
2\end{array}$ \\
\hline Plasma & $\left\{\begin{array}{l}0.05 \\
0.1 \\
0.2\end{array}\right.$ & ") & 0.5 & $\begin{array}{l}1.95 \\
1.90 \\
1.80\end{array}$ & $\begin{array}{l}2 \\
2 \\
2\end{array}$ & $\begin{array}{l}2 \\
2 \\
3\end{array}$ & $\begin{array}{l}2 \\
3 \\
2\end{array}$ & $\begin{array}{l}2 \\
3 \\
4\end{array}$ & $\begin{array}{l}2 \\
1 \\
2\end{array}$ \\
\hline $\begin{array}{l}\text { Plasma } \\
\text { protein } \\
\text { solution }\end{array}$ & $\left\{\begin{array}{l}0.05 \\
0.1 \\
0.2\end{array}\right.$ & "' & 0.5 & $\begin{array}{l}1.95 \\
1.90 \\
1.80\end{array}$ & $\begin{array}{l}1 \\
2 \\
1\end{array}$ & $\begin{array}{l}2 \\
2 \\
2\end{array}$ & $\begin{array}{l}2 \\
2 \\
2\end{array}$ & $\begin{array}{l}2 \\
4 \\
3\end{array}$ & $\begin{array}{l}2 \\
2 \\
2\end{array}$ \\
\hline Macrodex & $\left\{\begin{array}{l}0.05 \\
0.1 \\
0.2\end{array}\right.$, & ,", & 0.5 & $\begin{array}{l}1.95 \\
1.90 \\
1.80\end{array}$ & $\begin{array}{r}6 \\
7 \\
12\end{array}$ & $\begin{array}{l}5 \\
7 \\
9\end{array}$ & $\begin{array}{r}4 \\
8 \\
12\end{array}$ & $\begin{array}{r}6 \\
9 \\
13\end{array}$ & $\begin{array}{r}3 \\
6 \\
10\end{array}$ \\
\hline $\begin{array}{c}\text { Dextran } \\
110\end{array}$ & $\left\{\begin{array}{l}0.05 \\
0.1 \\
0.2\end{array}\right.$ & ”, & 0.5 & $\begin{array}{l}1.95 \\
1.90 \\
1.80\end{array}$ & $\begin{array}{l}10 \\
42 \\
63\end{array}$ & $\begin{array}{l}15 \\
49 \\
62\end{array}$ & $\begin{array}{l}14 \\
50 \\
61\end{array}$ & $\begin{array}{l}18 \\
53 \\
70\end{array}$ & $\begin{array}{l}17 \\
47 \\
59\end{array}$ \\
\hline $\begin{array}{c}\text { Dextran } \\
150\end{array}$ & $\left\{\begin{array}{l}0.05 \\
0.01 \\
0.2\end{array}\right.$ & "; & 0.5 & $\begin{array}{l}1.95 \\
1.90 \\
1.80\end{array}$ & $\begin{array}{l}18 \\
69 \\
88\end{array}$ & $\begin{array}{l}18 \\
67 \\
85\end{array}$ & $\begin{array}{l}24 \\
65 \\
93\end{array}$ & $\begin{array}{l}27 \\
75 \\
97\end{array}$ & $\begin{array}{l}19 \\
70 \\
82\end{array}$ \\
\hline
\end{tabular}

TABLE II.-Effect on Erythrocyte Sedimentation Rate of Artificially Produced Anaemia. Added Transfusion Material is Present at a Concentration of 1 in $10.100 \%=14.6 \mathrm{~g}$. of Haemoglobin per 100 ml. Blood

\begin{tabular}{|c|c|c|c|c|c|c|c|}
\hline \multirow{2}{*}{$\begin{array}{c}\text { Haemo- } \\
\text { globin } \\
(\%)\end{array}$} & \multirow[b]{2}{*}{ Test } & \multicolumn{6}{|c|}{ E.S.R. (mm. in 1st hr.) (Westergren) } \\
\hline & & Saline & Plasma & $\begin{array}{c}\text { Plasma } \\
\text { Protein } \\
\text { Sol. }\end{array}$ & Macrodex & $\underset{110}{\text { Dextran }}$ & $\underset{150}{\text { Dextran }}$ \\
\hline 30 & $\begin{array}{r}\text { I } \\
\text { III } \\
\text { III }\end{array}$ & $\begin{array}{l}8 \\
5 \\
6\end{array}$ & $\begin{array}{l}6 \\
9 \\
5\end{array}$ & $\begin{array}{l}7 \\
5 \\
8\end{array}$ & $\begin{array}{l}28 \\
16 \\
25\end{array}$ & $\begin{array}{r}94 \\
102 \\
84\end{array}$ & $\begin{array}{l}129 \\
118 \\
113\end{array}$ \\
\hline 40 & II & $\begin{array}{l}8 \\
4 \\
6\end{array}$ & $\begin{array}{l}4 \\
9 \\
5\end{array}$ & $\begin{array}{l}7 \\
5 \\
7\end{array}$ & $\begin{array}{l}27 \\
16 \\
23\end{array}$ & $\begin{array}{r}90 \\
100 \\
79\end{array}$ & $\begin{array}{l}129 \\
111 \\
112\end{array}$ \\
\hline 50 & II & $\begin{array}{l}7 \\
2 \\
5\end{array}$ & $\begin{array}{l}5 \\
8 \\
5\end{array}$ & $\begin{array}{l}6 \\
5 \\
7\end{array}$ & $\begin{array}{l}27 \\
16 \\
22\end{array}$ & $\begin{array}{l}89 \\
95 \\
72\end{array}$ & $\begin{array}{l}127 \\
110 \\
108\end{array}$ \\
\hline 60 & II & $\begin{array}{l}5 \\
2 \\
5\end{array}$ & $\begin{array}{l}5 \\
6 \\
5\end{array}$ & $\begin{array}{l}5 \\
3 \\
6\end{array}$ & $\begin{array}{l}25 \\
15 \\
22\end{array}$ & $\begin{array}{l}88 \\
90 \\
71\end{array}$ & $\begin{array}{l}119 \\
110 \\
103\end{array}$ \\
\hline 70 & II & $\begin{array}{l}4 \\
2 \\
3\end{array}$ & $\begin{array}{l}4 \\
5 \\
3\end{array}$ & $\begin{array}{l}6 \\
3 \\
4\end{array}$ & $\begin{array}{l}24 \\
12 \\
18\end{array}$ & $\begin{array}{l}85 \\
87 \\
71\end{array}$ & $\begin{array}{r}117 \\
96 \\
103\end{array}$ \\
\hline 80 & II & $\begin{array}{l}3 \\
3 \\
3\end{array}$ & $\begin{array}{l}2 \\
5 \\
3\end{array}$ & $\begin{array}{l}4 \\
3 \\
2\end{array}$ & $\begin{array}{l}21 \\
11 \\
16\end{array}$ & $\begin{array}{l}80 \\
85 \\
69\end{array}$ & $\begin{array}{r}115 \\
98 \\
99\end{array}$ \\
\hline 90 & II & $\begin{array}{l}2 \\
2 \\
3\end{array}$ & $\begin{array}{l}2 \\
5 \\
2\end{array}$ & $\begin{array}{l}3 \\
3 \\
2\end{array}$ & $\begin{array}{l}21 \\
11 \\
13\end{array}$ & $\begin{array}{l}70 \\
86 \\
63\end{array}$ & $\begin{array}{r}108 \\
97 \\
95\end{array}$ \\
\hline 100 & $\begin{array}{r}\text { I } \\
\text { III }\end{array}$ & $\begin{array}{l}2 \\
2 \\
2\end{array}$ & $\begin{array}{l}1 \\
4 \\
2\end{array}$ & $\begin{array}{l}3 \\
3 \\
1\end{array}$ & $\begin{array}{l}18 \\
11 \\
13\end{array}$ & $\begin{array}{l}71 \\
82 \\
60\end{array}$ & $\begin{array}{r}104 \\
98 \\
90\end{array}$ \\
\hline 110 & II & $\begin{array}{l}2 \\
2 \\
3\end{array}$ & $\begin{array}{l}2 \\
4 \\
2\end{array}$ & $\begin{array}{l}2 \\
3 \\
2\end{array}$ & $\begin{array}{l}13 \\
12 \\
10\end{array}$ & $\begin{array}{l}70 \\
80 \\
59\end{array}$ & $\begin{array}{l}96 \\
98 \\
88\end{array}$ \\
\hline
\end{tabular}

to the naked eye and some rouleaux formation was seen on microscopy (Fig. 1). Both dextran 110 and dextran 150 produced a coarse granulation, macroscopically resembling agglutination. Under the microscope, aggregation of red cells into large masses almost impossible to distinguish as rouleaux could be seen. This effect was only slightly less marked with dextran 110 (Fig. 2) than with dextran 150.

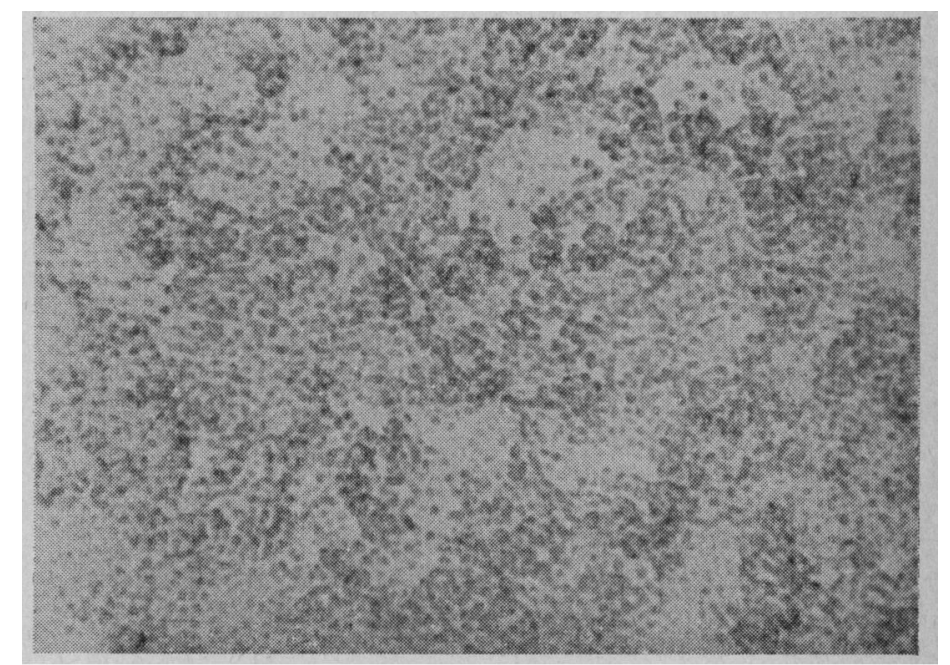

FIg. 1.-Rouleaux formation in a saline cross-match containing Macrodex.

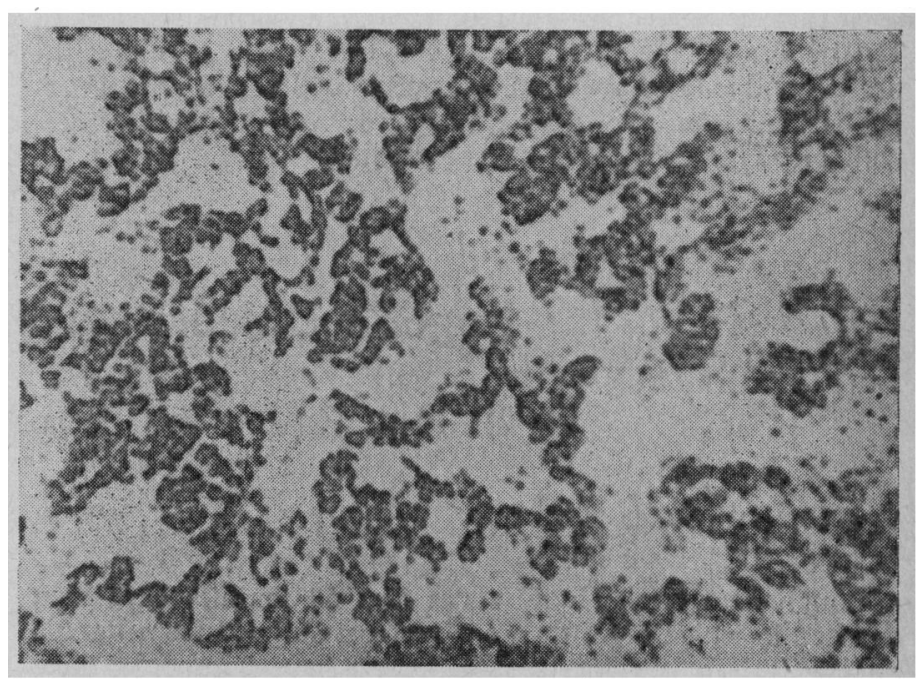
FIG. 2.-Rouleaux formation in a saline cross-match containing dextran
110 .

\section{Discussion}

The in vitro addition of plasma or plasma-protein solution to blood was found to have a virtually negligible effect upon rouleaux formation and the erythrocyte sedimentation rate. On the other hand, all dextrans tested under these conditions produced some rouleaux formation and an increase in sedimentation rate. Of the dextrans, Macrodex exerted the least effect. Rouleaux formation was slight and the increase in sedimentation rate only moderate. The rouleaux formation was readily recognized microscopically and was unlikely to lead to any difficulty in blood grouping and cross-matching. These findings were in agreement with previous reports on the effect of Macrodex upon blood typing and cross-matching (Turner et al., 1949 ; Bloom, 1951 ; Roche et al., 1952 ; Bowman, 1953 ; ArndtHanser, 1956 ; Pettenkofer, 1959 ; Haynes, 1960).

Surprisingly, dextran 110 produced rouleaux formation as readily as dextran 150 . The degree of rouleaux formation was 
severe enough to cause considerable difficulty in blood grouping and saline cross-matching. There are at present few published accounts dealing with this aspect of dextran 110. Ricketts (1966) found rouleaux formation a hindrance to satisfactory saline cross-matching in only two cases, and then with serum concentrations of modified dextran considerably higher than in the present investigation. Though Ricketts found a moderate increase in E.S.R. with modified dextran in experiments in vitro, this could not be compared directly with the marked increase noted here, since Ricketts used the Wintrobe method for estimating the E.S.R.

There is a critical level of molecular weight so far as rouleaux formation by dextrans is concerned (Thorsén and Hint, 1950). Dextrans with an average molecular weight below 60,000 cause no increase in sedimentation rate. As the molecular weight increases above 60,000 , red-cell rouleaux formation appears and the sedimentation rate rises progressively.

Macrodex has an average molecular weight of about 70,000. About $10 \%$ of the preparation has a mean molecular weight of 108,000 and $9 \%$ of 25,800 (Kjellman, 1965 ; Rousell, 1966 ; Nilsson, 1967). Hence on average Macrodex is only slightly above the critical molecular weight. Dextran 110 has an average molecular weight of about 110,000. Ten per cent. of the preparation has a mean molecular weight of 194,000 , and $8 \%$ of 35,000 (Nilsson, 1967). This is reflected in an increased tendency to cause rouleaux formation and a rise in the erythrocyte sedimentation rate.

Thus from the point of view of effective blood grouping and cross-matching it would seem essential to take blood from a patient for these purposes before administration of dextran 110 or dextran 150 . If immediate transfusion before withdrawal of blood is required Macrodex will cause little interference, and plasma or plasma-protein solution no interference, with blood grouping and cross-matching.

\section{Summary}

Plasma, plasma-protein solution, Macrodex, dextran 110, and dextran 150 were compared for their effect upon red-cell rouleaux formation and erythrocyte sedimentation rate in a series of in vitro experiments.

Plasma and plasma-protein solution do not produce rouleaux formation and have no effect upon the sedimentation rate. Macrodex, in concentrations likely to be found in plasma, does not caused marked rouleaux formation. Therefore administration of these substances before the taking of blood is unlikely to lead to any difficulty in blood grouping and cross-matching.

In contrast, both dextran 110 and dextran 150 produce marked rouleaux formation and a considerable rise in the E.S.R. They are likely to interfere with blood grouping and crossmatching, and should be given to a patient only after blood has been withdrawn.

Many thanks are due to Professor D. L. Mollin for the great interest that he has shown in this paper and for his many helpful comments.

\section{REFERENCES}

Arndt-Hanser, A. (1956). Bibl. haemat. (Basel), 5, 181.

Bloom, W. L. (1951). Arch. Surg., 63, 739.

Bowman, H. W. (1953). 7. Amer. med. Ass., 153, 24.

Brit. med. . ., 1967, 1, 363 .

Haynes, B. W. (1760). Amer. 7. Surg., 99, 684.

Haynes, B. W. (1960). Amer 7. Surg., 99, 684.

Mollison, P. L. (1967). Blood Transfusion in Clinical Medicine, 4 th ed. Oxford.

Nilsson, K. (1967). Personal communication.

Pettenkofer, H. J. (1959). Chirurg, 30, 25.

Ricketts, C. R. (1966). Brit. med ł., 2, 1423.

Roche, P., jun., Dodelin, R. A., and Bloom, W. L. (1952). Blood, 7, 373.

Rousell, R. H.' (1966). Brit. med. 7., 2, 691.

Thorsén, G., and Hint. H. (1950). Acta chir. scand., Suppl. No. 154.

Turner, F. P.. Butler, B. C., Smith, M. E., and Scudder, J. (1949). Surg. Gynec. Obstet.. 88, 661 .

\section{Paget's Disease : a Family with Six Cases}

\section{J. VERRIER JONES,* B.M., M.R.C.P. ; MERVYN F. REED, $†$ M.в., CH.B.}

Brit. med.F., 1967, 4, 90-91

Although McKusick (1966) states that 52 families have been reported in which more than one member suffered from Paget's disease, it is a striking fact that there have been only three reports of familial Paget's disease occurring in Great Britain. Kilner (1904) recorded an affected brother and sister, and Smith (1905) an affected father and son. Rast and Weber (1937) described the cases of three affected sisters. The literature on familial Paget's disease has been fully reviewed by Ravault, Lejeune, Robert, and Maitrepierre (1963) and by McKusick (1966). Records have been published of one family with four confirmed and two probable cases (Ravault et al., 1963), two families with six cases (Hanke, 1935 ; Dickson, Camp, and Ghormley, 1945), and one family with five cases (van Bogaert, 1933). The remainder of the reports are of smaller families. McKusick (1966) draws attention to the difficulty of studying the familial incidence of a disease which is often asymptomatic, and suggests that "it may be that a study of families using alkaline phosphatase determinations as a screening procedure would be productive."

The purpose of this paper is to put on record an English family in which six cases of Paget's disease have occurred in three generations, and in which nine unaffected members of

- Senior Medical Registrar, Bristol General Hospital, Bristol.

+ Registrar in Obstetrics and Gynaecology, Southmead Hospital, Bristol. the family have been studied. Radiological investigations and alkaline phosphatase estimations have been made in 13 members of the family.

\section{The Family}

Details of the family are set out in the genealogical diagram and in the Table. Thirteen members of the family were visited. All were examined clinically, $x$-ray films of the pelvis and tibiae were taken, and the alkaline phosphatase was estimated. In the case of two members of the family who were dead (I 1 and II 3) it was possible to make a diagnosis of Paget's disease with reasonable certainty from the evidence given by the rest of the family. Four living members of the family had clinical Paget's disease (details are given in the Table), and in all of these the alkaline phosphatase was raised. Nine members, ranging in age from 81 to 17 years, had no clinical evidence of Paget's disease, and their bone radiographs and alkaline phosphatase were normal. The age of onset of Paget's disease in this family seems to be in the decade 40 to 50 . Three of the unaffected members are in this age group, and are therefore likely to remain unaffected. Of the remaining six (aged 17 to 29) several are likely to develop the disease in later life. This study suggests that there are no early $x$-ray changes or abnor- 